\title{
Quo Vadis? Quo Vadimus?
}

Dear readers,

present situation in European higher education brings a wide range of issues. New laws and new rules often burden us with superfluous administration. Therefore, it is worth asking the question from time to time, where we are heading for and what is the sense of our activity.

\section{Quo Vadis, financial and accounting science?}

To formal fullness or to real creativity? What brings financial and accounting science really new? Does it discover and invent or does it simply talk and talk? When did it actually help to mankind? Did it manage to prevent any financial and economic crisis, or has it in fact contributed to the emergence of these crises?

At present, our social science often focuses only on interpretation of legal rules and contributes little to make these laws and other rules better. Instead of creating new things, we are just studying what new came from above and what effect it is going to have on us as patients.

Empirical studies are a popular methodical tool. To the success of such studies, as every good explorer knows, it is necessary to choose a representative sample, which leads to the fulfilment of his wishes. And because different authors choose different samples and use slightly different methods, individual authors may argue almost to infinity, which one of them is right. Questionnaires create perhaps an even better illusion. Some researchers work with just a small number of respondents, others increase it with a computer. The biggest joke is that these respondents usually answer differently from what they actually think, if they understand the meaning of the question at all. When did new ideas and models emerge for the last time? Let's ask ourselves the question whether it was in the days of Miller, Modigliani, Markowitz and Sharpe and whether today's models are not just all sorts of modifications of the original models. We are competing for the better value of beta coefficient, and we care less about what it is actually good for. 
Janusz Zajdel describes in his science fiction book Limes Inferior ${ }^{l}$ the planet Argoland, a fictional world in which an electronic system of biometric identification keys plays an important role. These keys are used as a national identity card, a passport, a working book or a credit card. There is the Research Institute which deals with the issue of functioning of keys. However, this Institute does surprisingly not deal with how to improve the key, but it delves into how this key works. No one knows who actually invented this key. The author gives it away eventually. It was aliens who verify experimentally their social and economic ideas using humans first. And I am afraid, that I sometimes feel as if I am on the planet Argoland, living in a similar lab, where unknown persons test their social and economic experiments on people.

Successful scientist is a person not by inventing something, but by writing about what he or she invented somewhere, where someone else reads it and cites it in own publication. This is why I do not know if we write books and scientific articles today, because we enjoy it, or just multiply our old articles to meet the publication quota someone has established. Sometimes it seems to me that we only write and write, but we do not read what others have written, so we often come to same bland conclusions like other authors before us. This often leads to clientelism in large journals. New authors push their work through with great difficulties, while friends of members of editorial boards can come with any nonsense.

\section{Quo Vadis, finance and accounting education?}

To production of thousands of new students or to the upbringing of new economically thinking experts? What do present students want? Knowledge and skills or just academic titles? There are of course different students, some yearn for knowledge and other just not to be bothered too much. The advantage of the system we have today lies in the fact that students can choose their own path, either the less demanding with less skills earned or much more difficult with higher benefits. Less and less prepared students are coming to us from secondary schools. Contemporary college student has trouble with keeping attention for

1 Zajdel, J.: Limes Inferior. Warszawa, Iskry, 1989. 
longer than 15 minutes. I'm afraid that in Kim's memory game, most of them would not succeed today. ${ }^{2}$

What do political representatives want? Political representatives are eager for the satisfaction of voters (the government coalition) or for the dissatisfaction of voters (the opposition). And let's face it - there are far more voters on the part of students and their relatives than voters on the part of teachers. Therefore, the education of the nation is measured by quantity, the more graduates the better, but it proves unfortunately nothing about quality of education. Problems of public universities are beneficial to private universities, and even in this can be found motivation of our politicians.

What does a practice want? Requirements vary from employer to employer. Some employers want students who do not need further training, others, by contrast, want only students learned to think economically, teaching them everything else with a few exceptions. But do we really manage to learn students to think economically? When students actually think independently during the tuition? What do actually students remember from classes? What is the point of lessons? The responsibility lies mainly with teachers - how they give lectures, whether they just jabber or give students food for thought. However, it is of course necessary for the student to at least go to the lecture. What do students remember from classes in fact? Do they not forget five minutes after the test everything previously learned (or mugged up)?

\section{I dare say that I am optimist, because it is still not so bad that it could not be worse.}

prof. Ing. Petr Marek, CSc.

Chairman of Editorial board

European Financial and Accounting Journal

\footnotetext{
2 A note for those who do not have an experience with the Scout Association: Here, the name Kim is not derived from the name of Korean leader, but from a character from Kipling's novel from the beginning of last century (see Kipling, R.: Kim. London, Macmillan, 1901).
} 